Delft University of Technology

\title{
The resurgence of regional design
}

Neuman, Michael; Zonneveld, Wil

DOI

10.1080/09654313.2018.1464127

Publication date

2018

Document Version

Final published version

Published in

European Planning Studies

\section{Citation (APA)}

Neuman, M., \& Zonneveld, W. (2018). The resurgence of regional design. European Planning Studies, 26(7), 1297-1311. https://doi.org/10.1080/09654313.2018.1464127

\section{Important note}

To cite this publication, please use the final published version (if applicable).

Please check the document version above.

\section{Copyright}

Other than for strictly personal use, it is not permitted to download, forward or distribute the text or part of it, without the consent of the author(s) and/or copyright holder(s), unless the work is under an open content license such as Creative Commons.

\section{Takedown policy}

Please contact us and provide details if you believe this document breaches copyrights.

We will remove access to the work immediately and investigate your claim. 
Green Open Access added to TU Delft Institutional Repository

'You share, we take care!' - Taverne project

https://www.openaccess.nl/en/you-share-we-take-care

Otherwise as indicated in the copyright section: the publisher is the copyright holder of this work and the author uses the Dutch legislation to make this work public. 


\section{The resurgence of regional design}

\section{Michael Neuman \& Wil Zonneveld}

To cite this article: Michael Neuman \& Wil Zonneveld (2018) The resurgence of regional design, European Planning Studies, 26:7, 1297-1311, DOI: 10.1080/09654313.2018.1464127

To link to this article: https://doi.org/10.1080/09654313.2018.1464127

\section{Published online: 17 Apr 2018.}

\section{Submit your article to this journal $₫$}

LII Article views: 319

Q View related articles $\square$

View Crossmark data \lceil

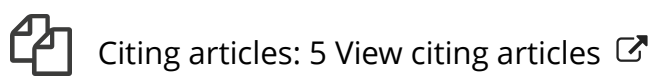




\title{
The resurgence of regional design
}

\author{
Michael Neuman ${ }^{a}$ and Wil Zonneveld ${ }^{b}$ \\ ${ }^{a}$ Sustainable Urbanism, Faculty of Architecture and the Built Environment, University of Westminster, London,

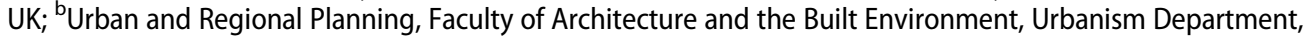 \\ Spatial Planning and Strategy Section, Delft University of Technology, Delft, Netherlands
}

\begin{abstract}
Regional design, long a backbone for spatial planning, even if under other names, has become topical again for two reasons - as a key strategy and as a key tool in spatial management. This is due to several reasons. New conditions of urbanization that result from the convergence of several factors highlight the need for spatial strategy formation and application at supra-metropolitan scales. These new conditions include globalization, climate change, booming urban population, increased mobility and interconnectivity, and new infrastructure technologies. These forces driving urbanization today and into the future play out at the urban scale, which is increasingly encompassed in the cityregion. The solutions to the impacts and problems that these forces cause must be dealt with by a strategic urbanism at a scale that matches. This scale of urbanism can be denoted as regional design. To justify these claims and to understand the origins of regional design and its relevance today and into the future, the master strokes in its history are presented next. After that, we discuss current concepts and practices in regional design. In conclusion, we offer answers to the question: why a resurgence of regional design?
\end{abstract}

\section{ARTICLE HISTORY}

Received 28 November 2017

Revised 4 April 2018

Accepted 5 April 2018

\section{KEYWORDS}

Region; urban; planning; policy; strategy; city-region

\section{Why now}

Regional design, long a backbone for spatial planning, even if under other names, has become topical again for two reasons - as a key tool for spatial strategy and as a key tool in spatial management. This is due to several reasons. New conditions of urbanization that result from the convergence of several factors highlight the need for spatial strategy formation and application at supra-metropolitan scales. These new conditions include globalization and climate change along with all their impacts, as well as the urban population boom enabled by increased mobility and interconnectivity, along with new infrastructure technologies. These forces driving urbanization today and into the future play out at a new urban scale, which is increasingly encompassed in the city-region. The solutions to the impacts and problems that these forces cause must be dealt with by urbanism at a scale that matches. Strategic solutions to this scale of urbanism can be denoted as regional design.

CONTACT Michael Neuman m.neuman@westminster.ac.uk $\Theta$ Sustainable Urbanism, Faculty of Architecture and the Built Environment, University of Westminster, 35 Marylebone Road, London NW1 5LS, UK 
Yet older factors, including those stemming from the problematic impacts of cityregion growth and development that have remained unsolved for generations despite best efforts, still provide impetus for regional design. Factors such as housing affordability, socio-spatial inequity, traffic congestion and air and water pollution, among others, have city-region sources and need holistic city-region-wide solutions. These persistent factors also can be, and have been, effectively dealt with by regional design.

This is because traditional urban planning, conceived at the neighbourhood, district, city or even metropolitan scale, is inadequate to deal with many pressing urban problems and opportunities today, and into the future. Often the causes of these problems arise at regional and even larger scales (Alawadi \& Benkraouda, 2017; Burger, O’Neill, Handel, Hensold, \& Ford, 2017). Moreover, traditional statutory planning in general regulates the use of space, hardly offering a strategic orientation, as it is strictly local in nearly all countries (Ryser \& Franchini, 2015). Further, in its emphasis on place and zoning, traditional urban planning omits flows and processes (Neuman, 2005).

Thus, by being strategic, by focusing on the scale that provides critical context for urban planning at local and metropolitan scales, by addressing supra-urban issues and by addressing the flows that infrastructures convey, regional design has been re-emerging in the forefront of spatial planning. Its focus is a bit sharper than spatial planning, as discussed herein. As we will argue below, regional design can also be seen as a partial response to the procedural and communicative turn in planning which took place in many countries in the 1980s and 1990s. This 'turn' moved planning away from space and territory into the direction of process, collaboration and negotiation.

Regional design takes into account spatial parameters to undertake both analysis (understanding the problematic) and synthesis (formulating spatial solutions) at the regional scale through the use of a wide range of spatial imageries. Its rationale, as evidenced and synthesized from the practice and literature reviewed here, stems from:

(1) the increase in scale and connectivity among neighbouring metropolises to form large city regions;

(2) the influence of transport, water, energy, telecommunications and knowledge infrastructures as drivers of regional agglomerations;

(3) the multi-scalar realities of glocal processes and spatial formation;

(4) the twin and inter-related imperatives of competitiveness and sustainability necessitate larger scale, holistic thinking;

(5) the multiple levels of governance in concert with other sectors of society that are needed to address intertwined regional and local issues in new ways that traditional government and its planning have not been able to perform.

These factors combine and permute to reassert the importance of the regional design of territorial forms and processes, including and especially governance: targeting public and private actors (Salet \& Faludi, 2000). In short, images as institution builders (Neuman, 1996). We will later refer to ongoing regional design activities in Asia (especially Japan and China), Europe (much of the continent) and North America (particularly the Texas Urban Triangle, the Northeastern Megalopolis, the Southeastern mega-region and Cascadia) that illustrate the resurgence of regional design, an element of the 
contemporary take on the broader resurgence of the design dimension in planning (Albrechts, Balducci, \& Hillier, 2016).

Regional design takes place in a setting where an entire range of boundaries has become blurred (Neuman, 2014). Being fuzzy at the edges not only relates to space but also to actors as well as to knowledge about spatial dynamics (De Roo \& Porter, 2016). 'The' region is difficult to demarcate - the fractured functional spaces of daily activity surpass contiguous administrative territories (Friedmann \& Weaver, 1980). Spaces and places are connected in many different ways, leading to complex, multi-scalar interrelations. The administrative borders of local and regional government no longer match these relations (Neuman, 2007). Critically, they no longer can match them. Existing formal (statutory) is that supra-local planning does not deliver orientation about the potentialities of space that is strong enough to contend with its domain. One main cause, in many countries, supra-local intervention is contested. Another, the legal-administrative arrangements and tools are no longer sufficient, as they were designed decades, even generations ago, to deal with simpler, smaller scale circumstances.

Regional design has the virtue of clarifying, at least in part, necessary changes in the governance of city-region development by focusing on strategic spatial characteristics. Strategic ones are selected because they induce growth and shape form and structure. These strategic matters that in many regional designs are spatially expressed by infrastructure are thus subject to investments that can spur economic activity and ecological restoration. By contrast, regulation and other development controls are more apt for smaller urban scales such as the municipality and specific projects. It is the larger scale and the associated level of complexity - in terms of governance as well as spatial structure which distinguishes regional design from urban design.

These are strong claims. Not all agree with them, whether in politics, in academia or across professional domains. At the outset of the preparation for the third regional plan for New York, Princeton architecture dean and noted urban designer Professor Robert Geddes commented 'you can't design a region'. Yet, after an extensive process of plan development, the New York Regional Plan Association (RPA) did just that. The RPA explicitly employed regional design as the strategic backbone of its 1996 regional plan (Yaro \& Hiss, 1996). It continues to do so in its most recent plan (Regional Plan Association, 2017). To justify these claims and to understand the origins of regional design and its relevance today and into the future, the master strokes in its history are presented next. After that, we discuss current concepts and practices in regional design and try to answer the question: why a resurgence of regional design? We round off with a brief conclusion.

\section{History and evolution of regional design}

Predecessors to regional design have a long and storied history that goes back a century and a half to the concepts proposed by the brilliant Ángel Fernández de los Ríos in his book El Futuro Madrid, published in 1868. He offered a detailed vision of the future of both the city of Madrid and its greater region, both in terms of a detailed analysis and a synthetic proposal for a regional vision, progressive for its time, recognizable to urbanists and regionalists today. His analysis befits a contemporary regional plan based on analytical methods first proposed by Patrick Geddes as 'survey before plan' (1915) a half century 
later. They were given more contemporary ecological expression in Ian McHarg's landmark book Design with Nature (1969), one century after Fernández de los Ríos.

The Spaniard's comprehensiveness included geologic, demographic, climatic, landscape, architectural, educational, economic and historic elements, among others, to determine the 'suitability' of urbanization. It is also notable for the central and strategic role accorded to infrastructure, especially transport and water. While virtually unknown outside of Spain, this remarkable book merits translation, as he reached beyond the urban scale of his Spanish contemporary Ildefons Cerdà (Neuman, 2000, 2011). It is a striking precedent for McHarg's 'layer' method of suitability analysis, itself a landmark as the basis for GIS (Spirn, 2000).

In the early twentieth century, regional design thinking was further elaborated in Anglo-Saxon thought by Ebenezer Howard, Patrick Geddes, Thomas Adams, Lewis Mumford, Benton MacKaye and others on both sides of the Atlantic. Their contributions, including the Garden City, as networked in a rural region, by Howard (1898), the Valley Section by Geddes (1915), the Townless Highway by Mumford and MacKaye (1931), the Appalachian Trail by MacKaye (1921) and New York's regional plan (1929), along with the 'counterplan' by the Regional Planning Association of America (1925) were put in to practice in Europe, North America and beyond since the 1920s.

As regional planning practices evolved, other leading proponents included the Randstad surrounding the Green Heart in the Netherlands in its basic form unveiled as early as 1924 (Faludi \& Van der Valk, 1994), the 1945 Greater London Plan of Patrick Abercrombie, the Tennessee Valley Authority regional planning of the 1930s and 1940s, and the 1939 Gran Madrid Plan of Pedro Bidagor. In the pre-Second World War era, leading practitioners of planning in most European and North American nations were often designers - architects and landscape architects. They oriented planning, especially at the regional scale, mostly towards the physical urban environment. That is, regional planning was design oriented, using maps, spatial models, diagrams and other imageries as main devises to simultaneously express analytical understanding and normative thinking. Pre-war regional planning was a precursor to regional design.

The current resurgence in regional design in Europe can be seen in many countries beyond the Netherlands, which is generally seen as one leader (see, for instance, Salewski, 2012). The example of the 1997 'Structure Plan Flanders' is one instance that has drawn a lot of attention (Albrechts, 1999; Olesen \& Albrechts, 2017), not only because it is the first plan ever made on the level of the entire Flanders region. Its content is highly characterized by a heavy use of design tools such as spatial concepts, maps and images. Looking at its making, in our view it could only acquire such a character through the involvement of regional designers, in particular, Van den Broeck, also a leading figure behind the 1996 'Benelux Structural Outline', whose content mirrors strongly the Flemish plan (1997). Yet for both point and counterpoint to concepts and images as well as design in planning, see Faludi (1996).

Regional design comes under a variety of different names like outline, sketch, scheme, vision, strategy or even exhibition like Internationale Bauausstellung (IBA) which in English reads as International Architecture Exhibition, although this does not capture the German meaning as an IBA could have an entire region as its subject. The prime example here is the 1989-1999 IBA Emscher Park which - like its name suggests lasted for more than 10 years. It was meant to experiment with new concepts targeting 
transformation - and ecological cleansing - of a former industrial region. It has inspired regional design exercises across the globe as far as Australia like Melbourne 2030, addressing not just the city but the entire region (Kozlowski, 2006).

What is behind labels such as IBA and others mentioned above does not necessarily restrict regional design to a design, plan or strategy to be created or implemented in the traditional statutory sense. In most cases we know, it is rather as a signpost to possible futures, including scenarios, to be created and tested in processes where designers although playing a key role - collaborate with others (Neuman, 2016). The 'other' could be a government administrator, a representative of industry or an NGO, a resident and so forth. Regional design also can take place via a design competition, especially in cases where there is great uncertainty about how to manage pressing issues (Bisker, Chester, \& Eisenberg, 2015; National Infrastructure Commission, 2017a, 2017b).

Another significant example is 'Rebuild by Design', a design exercise initiated after hurricane Sandy hit the northeast of the USA in 2012. As its namesake website indicates, it 'convenes a mix of sectors - including government, business, non-profit, and community organizations - to gain a better understanding of how overlapping environmental and human-made vulnerabilities leave cities and regions at risk'. While regional designers are not explicitly mentioned, a Dutch water envoy - himself an urban designer - has been highly influential framing the search for strategies to deal with flood management as a design competition (Bisker et al., 2015; Ovink, 2015).

What all these examples have in common is that regional design is not just physical design. ${ }^{1}$ Design is also a process - in the sense of creating. The process of regional design, when conducted well, creates governance capacity. Physical designers and other professionals having the capacity to design play an important role in these processes because at the regional scale and complexity of design, novel governance institutions, structures, processes and means must be created. These processes are designed, as are the institutions in which they are embedded. This is an emergent and critical role for regional design 'as a process'. Regional designers organized and acting in such a way enables their expertise to manifest itself, for instance, through the creation of design studios (see, for instance, Balz \& Zonneveld, 2015), charettes or competitions.

Regional design - at least in the examples mentioned - is also connected to politics, the full scope of which is outside the scope of this article. Success is not guaranteed, though, in large part due to politics and governance complexity. The design of regions, by its very nature, crosses administrative boundaries. Scores, and often, hundreds of organizational actors can be engaged. Inevitably, it results in conflict and disagreement, entrenched as they are in existing institutions.

Across the Atlantic in North America, contemporaneously yet without the level of trans-Atlantic dialogue evident in the 1920s largely through Robert Adams's and Werner Hegemann's efforts (Hegemann \& Peets, 1922), the resurgence of regional design began with the New Jersey State Plan that had as its strategic backbone the Regional Design System, articulated in 1989. In the New Jersey State Plan, titled 'Communities of Place' regional design provided a spatial framework for its policies and strategies. Key principles underlying regional design in the State Plan were a hierarchy of settlements arrayed in a region, connected by infrastructure networks and buffered by rural and ecological environs (Center for Urban Policy Research, 1992; New Jersey Office of State Planning, 1990; New Jersey State Planning Commission, 1992). 
The regional design strategy of the New Jersey State Plan synthesized, in part, some of the principles in Lynch (1976), McHarg (1969) and Alexander et al. (1977), as applied to the highly urbanized territory of New Jersey. Since then it has been used as a touchstone for the RPA's third Plan for New York and Environs (Yaro \& Hiss, 1996), and the subject of several books (Kelbaugh, 1997; Lewis, 1996).

Other examples that did include trans-Atlantic dialogue include mega-region planning in the US in the Texas Urban Triangle, and the 10 mega-regions under the joint auspices the New York RPA, America 2050, and several universities (Lang \& Knox, 2009). It is also occurring as a response to climate change-induced severe storms such as those in the New Orleans/Mississippi River delta, New York (White, 2015) and Houston.

\section{Current concepts and practices in regional design}

Settlements and their planning get played out in the landscape in built form. In a region of any type, its spatial components are organized into networks. In this sense, regional design can be seen as network urbanism (Dupuy, 1991) at the regional scale. In the human built environment, key components at the regional scale include settlements, infrastructure linkages/networks and the spaces in between the settlements that the infrastructure networks traverse. Therefore, any responsible approach to regional planning is realized by design of the physical aspects of the built environment, along with the socio-economic and governance aspects. While this is well settled in cities at the urban scale through long established practices of urban design and physical urban planning, at the regional scale the physical components have tended to be less integrated through strategic and holistic design. This has been due to the infrequent existence of governance conditions that support a strategic and holistic approach on regional levels and the related (heavy) emphasis on processes, procedures and consensus-building which ultimately may even lead to what some call 'negotiated nonsense' (De Bruijn \& Ten Heuvelhof, 1999; Van de Riet, 2003). This is the downside of communicative and collaborative approaches in planning practice and literature: a lack of attention towards the content of plans and planning, the 'storytelling' (Throgmorton, 1996, 2003) dimension of planning. In our view, the resurgence of regional design, has partly been a reaction to the emphasis on process, bringing about a better balance between them.

Regional design is the practice of guiding human settlement in a region by shaping the size, function, location and inter-relations of settlements; as well as the relation of those settlements to their environs. Regional design thus guides the flows of human activities related to settlements via the infrastructure linkages among them (given a broad understanding of what constitutes 'infrastructure'). In so doing, regional design addresses the integration of settlements and infrastructure networks with ecological patterns to attain the greatest degree of sustainability available. Finally, regionally design recently also touches upon flood management in large-scale water systems - river basins and delta and coastal areas - in relation to land-use and patterns of metropolitan development. This flood management aspect has been bolstered by catastrophic damage caused by severe storms, and corresponding efforts at recovery and at building future resilience and mitigation. In sum, regional design concerns the physical design of a region which includes all sorts of non-physical connectivities made possible through physical infrastructure. As such it provides a context for urban and community design. To a certain extent, 
regional design is to a region as urban design is to a city and architectural design is to a building.

Regional design focuses on the spatial - that is, physical design, which is visualized by maps, physical plans and designs. At the same time, regional design is related to and the same time distinguished from (1) spatial planning (as practiced in Europe), (2) strategic planning, (3) spatial strategies and (4) strategic spatial planning. For example, spatial strategies can be merely a collection of regional spatial objectives or regional scale mega-projects like, for instance, the 2050 regional development plan for the Stockholm region. This class of planning documents does not necessarily have the fully integrative ambition intrinsically connected to regional spatial structure and the imaginative, forward looking ambition which regional design has. Our focus on regional design combines strategic (therefore selective) and integrative (therefore systemic) components (see also AlailyMattar, Thierstein, \& Förster, 2014). The tension among these components accounts for the complexity of urban regions today, where transformative ambitions are situated in a dynamic setting of governance with its real-life actors and their contestations in attempting to solve persistent and wicked problems.

The practices of regional design have become increasingly sophisticated with the advances in geographic, modelling, computational and visualization technologies and methods. The importance of regional design in these times can be found in the imperatives stemming from the impacts of new infrastructures and technologies, emergent sociospatial-economic processes, dramatic evolution in spatial governance and the proliferation of stakeholders, and the increasing urgency of addressing climate change, natural disasters, and refugee and migrant movements, among others.

Regional design consciously considers the spatial nature of settlement patterns in a region. Four aspects of settlement patterns are most pertinent (strategic) at the regional scale $^{2}$ :

(1) settlement location, size, function and their inter-relations within a determined region;

(2) infrastructure networks in all their varied forms that link the flows among settlements within a region and to other settlements and regions;

(3) the environs, understood as the lands and water bodies outside the settlements which the infrastructure networks traverse;

(4) the institutions, which govern regional analysis, planning, design and development.

These four components combine to demarcate the intellectual territory of regional design in the spatial sense. In addition to this spatial aspect, the governance of regional design starts with institutional design at the regional level that brings actors together and assigns rights and responsibilities through legal and institutional apparati. This is the constitutional aspect of governance. The ongoing management of the development of the region is another function of regional governance. In this case, regional design, besides being a key element of regional spatial planning, can be a stimulus for the establishment of regional governance capacity. Regional design, as conceived by civil society actors in addition to professionals, is thus a disruptive force vis-a-vis established governing institutions of traditional land-use and spatial planning. 
This formulation will be familiar to planners and designers of spaces and places - the spatial and territorial realms. Yet what about processes and flows, and their relation to places? Any coherent and integrated approach to regional design needs to consider the complexities of glocal process of placemaking that addresses simultaneously these aspects of contemporary city regions and their design and governance:

Multi-scale - referring to spatial dimensions of territory;

Multi-level - referring to the layers of government;

Multi-function - referring to the substantive domains;

Multi-flow - referring to processes, their fluxes and the conduits that convey them;

Multi-sector - referring to the sectors of society;

Multi-disciplinary - referring to the professions engaged;

Multi-actor - referring to the multitude of actors which have or demand a stake.

One source of the disruptiveness of regional design stems from its stance as a design discipline. Design disciplines typically take into account the physical form of a given region, yet to be comprehensive and thus disruptive, they must take into account the fluxes generated by social and economic processes in and through the region. These fluxes always are carried through infrastructures, an integral and strategic part of regional design. Another source of the disruptive nature of regional design is its intellectual history, spanning the professions of architecture, landscape architecture, engineering, planning and sociology. This intellectual diversity impinges on its practice.

For example, nowadays in the Netherlands, it has been common, though not universal, that landscape architects are those who lead in the design of the region, which results in the emphasis on land, landscape and water; that is, ecological factors (De Jonge, 2009). In the US, it tends to be urban designers and urban planners, and in Spain and Italy it is architect-planners. Yet regardless of the histories of the intellectual development of regional design as practiced in different countries, its multiple demands nowadays leads to disruptive practices that are at the same time cross-, inter-, trans- and multi-disciplinary; leading to new conceptions of territory, new visions of the future and new practices to attain them.

The Dutch practice mentioned above can also be seen as 'hydraulic' regional design managing water at a regional scale. The long history in the Netherlands in the management of polders such as the Zuiderzee (its historic name) is now being exported around the world, to Southern Louisiana, the Pearl River Delta and New York, to name a few. In the Netherlands, hydraulic engineers drew up the water plans, except for the urban aspects. Villages and towns were drawn up by urban and landscape designers. Yet the dominance of engineers in the past leads to contemporary questions for further analysis, including how did that combination of professions work together? How were they brought together? To what extent were engineers effective in designing the synthetic frame in which other specialist disciplines/professions contributed? How has their role changed in the face of the contemporary contributions by landscape architects? Were any professions missing or subordinate to the extent of not being consequential? How did the emergent practice of 'working with water' break out of the civil-engineering straight jacket of 'fighting against water' (see, for instance, Meyer, Bobbink, \& Nijhuis, 2010). 
The Dutch experience provides one lens through which to consider the renaissance of regional design in many regions of the world. These regional efforts have often been spurred by responses to large-scale disasters, many of them water-related (flooding due to severe storms, for example). Their responses focused on adaptation, resilience and preparedness for future calamities. What better 'substrate' - water - to weave together regional territories, and what better 'substance' - water again - to understand and deal with the temporal flows that these devastating natural events occasion? More recently these questions have stimulated a new wave of design thinking about spatial structure on supra-local levels (Sijmons, Hugtenburg, Feddes, \& Van Hoorn, 2014).

\section{The design of regional governance}

The issues confronting contemporary city regions, such as transport, pollution, climate change, land conversion, housing affordability, infrastructure finance, economic and social disparities/inequities, knowledge creation, digitalization and disaster response, along with others, have strong regional and global causes and implications. A critical characteristic of these types of problems is that they are no longer merely local in origin and effect. They have supra-local, and in fact, multi-scale causes, interactions and impacts. Inter-local planning and design are no longer sufficient, not even at the metropolitan level. Yet on the other end of the spectrum, national and international policies and programmes are typically a-spatial. Thus they are not specific to/adapted for local and regional conditions. This shortcoming has led to many problems in the in-between realm of regional governance.

Regional design is one framework for practices at a range of scales, not only regional. For example, in Europe, regional design could inform the practices that implement policy and strategy in 'macro-regions' and cross-border regions (see below). Regional design is able to respond to these conditions and issues by focusing analysis and synthetic solutions - the main components of design - on intermediate scales often overlooked by both national and local/metropolitan planning and governance entities. It provides a responsive method to the trends that shape the contemporary urban formations known as the cityregion (Neuman \& Hull, 2011).

Regional issues, between supra-local and sub-national, imply revisioning and reforming institutions of governance for three key components of regional design: urban development for the settlements, environmental and rural management for the environs and infrastructure management for the physical networks that link the settlements. Effective governance for regional design entails collaborative, consensus seeking and inter- and multi-jurisdictional practices among and within levels of governance. Yet the size of contemporary regions, larger than the past due to increases in population as well as economic, social and political interactions, means that many regions cross political borders, including national ones. This makes governance more difficult due to the complexity of the interjurisdictional matters that arise from cross-border issues. Cross-border policy is a common topic in the European Union (EU), yet is not unique to Europe.

Cross-border planning, design and governance are becoming more prominent because the size of regions increases as activities become more interconnected. This is due in part to information and communications technologies, more rapid travel speeds, growing volumes of trade, tourism, migration and so on. A new term - 'macro-regions' - has 
been put in use in the EU that reflects this increase in scale. Macro-regions are transnational regions that encompass several countries that are connected by a common geophysical feature such as a sea, river or mountain range. They are intended for the development of 'macro-region strategies' that supplement national policy and legislation (European Commission, 2016). These functional regions tend to be larger than past regional planning and design approaches, and have received their conceptual start from the establishment of the North Sea Commission in 1989. The first strategy to be finalized targeted the Baltic Sea Region (Stead, 2014). ${ }^{3}$

Cross-border, transnational planning at the supra-national and continental scales have been initiated in Europe. They can be traced back to the origins of spatial planning in the Netherlands, Germany and France, and its transference to the EU in the 1980s and 1990s. Regional and supra-regional concepts like urban networks, polycentricity and metropolitan regions have been 'uploaded' (scaled up) from these countries in European-wide discourses and documents like the 1999 'European Spatial Development Perspective' (Faludi \& Waterhout, 2002) and transnational visions from the late 1990s (Zonneveld, 2005a, 2005b). Subsequently, they have been 'downloaded' back in national and sub-national planning (Cotella \& Janin Rivolin, 2011; Faludi, 2003a, 2003b).

In the past two decades, planning addressed entirely new scales - cross-border, transnational and even European. This started stimulating regional design approaches that parlayed their inherent creativity and innovation in intervening in these very large territories, which heretofore was virtually unknown. Spatial structures needed to be unveiled at these levels, and related policy agendas had to be identified. An entirely new visual language emerged, often highly metaphorical, in images and vocabulary such as Finger Plan, Corridor, Red Octopus, Archipelago, Pentagon, Blue Banana, Bunch of Grapes, etc. (Dühr, 2007; Dühr \& Zonneveld, 2012).

Where regional design is accompanied by complementary institutional design of regional governance, together they can fill the gaps in contemporary spatial planning by developing more effective regional laws, policies and integrative processes; if not fullblown regional institutions. These can enable the establishment and implementation of development and financial mechanisms for infrastructure investment, which in turn lessen regional inequalities, and for protection of regional land resources. While it may be useful in select places to establish regional government, it is not necessary.

Legal and policy instruments at the regional scale include tax reform for land and other real property, transfer of development rights schemes including development rights banks, impact fees and related mechanisms for infrastructure finance, land banking and regional value capture schemes to spread the costs and the benefits of new development and redevelopment. This illustrative sample (not a definitive list) can be put into place by a range of inter-institutional contractual agreements that entail creative institutional designs. Regional design prompts a reallocation of the capacities of governance institutions, and the rights and responsibilities of constituent institutions (levels of government) incident on the region. Regional design in this sense - as a form of informal 'interstitial' planning - becomes a matter of creating and enhancing institutional capacity (for an early example of US cases and theory, see Innes, Gruber, Neuman, \& Thompson, 1994).

Yet what is more important to note for the design of regional governance is the spatial dimensions of regions, that is, their place-based nature that is defined by specific regional characteristics such as identity, language, culture, geography, etc. Being place-based differs 
from the typically a-spatial nature of national and international policy. When considering regional design and institutional design together in this way, we witness a sort of yin-yang. One cannot prosper without the other. They are different sides of the same coin.

$$
\text { Institutional design } \rightleftarrows \text { regional design. }
$$

This implies a sort of spatial-institutional isomorphism in which the design of the spatial region corresponds with the design of its governance institutions (Neuman, 2007). Just as regional design is a form of large-scale network urbanism (Dupuy, 1991), regional governance is a form of networked governance (Hajer, 2010; Hajer \& Versteeg, 2005). However, we must be careful in extending this isomorphism analogy, in that isomorphism focuses only on the spatial. It is an incomplete analogy in that it does not focus on the processes and flows that shape the form(s) of a region and its governance.

\section{Conclusion}

As we can appreciate, the challenges that face contemporary city regions can seem daunting. The problems are complex, multi-layered and intertwined; all with spatial and processual ramifications at the regional scale, and with important impacts on actions and conditions at other scales of territory and levels of government. Yet this level of complexity does more than merely illustrate the limitations and inadequacies of levels of government up to a millennium old - municipalities, shires, counties; and even the more recent provinces, states and metropolises (see also Faludi, 2013).

Regional design is a field which is ripe for bold action at scales that match those of the phenomena which we seek to manage. A conservative approach would counsel known agents like municipalities, and known actions like zoning. Yet new fields of play are veritable institutional blank slates that can spawn new solutions less fettered by past blinders. As Clifford Geertz once wrote, 'the more orderly and straightforward a particular course of action looks, the more it seems ill-advised' (1983, p. 6). While his phrase applied to the complexity of local cultures, we can apply it to the complexity of governance cultures. Regional networks of governing institutions can seem not to be orderly, yet we can see that they are indispensable.

Communities in metropolises and city regions are where most people spend the vast majority of their lives residing, working, commuting and recreating. They go a long way in satisfying many human needs. The regional context and its design are necessary conditions for analysing and solving these local and metropolitan problems, made more apparent as the metropolis is expanding to the qualitatively different polycentric cityregion. Regional design provides a means to enhance the practices of planning and designing. While there are numerous critics of current approaches to solving urban problems, planners and designers using the proper tools can improve the human urban condition. If we succumb to our critics who suggest that planning is a marginal enterprise in the neoliberal era of global society, not only do we overlook the evidence of significant urban achievement in the last decades. We may fall into the trap Samuel Johnson noted when he stated 'Nothing will even be attempted if all possible objections must first be overcome'.

Regional design provides a toolbox that helps planners, designers and policy-makers overcome a number of objections to the limits of both local and national planning. This toolkit contains intellectual tools including theoretical frameworks and principles, 
as well as broadening of design thinking to address institutional matters in addition to spatial issues. It also contains practical tools including design methods of how to think about the design of spaces and flows at the regional scale, and how to design/redesign governance institutions and processes at the regional scale and their interactions with other institutions at other scales.

\section{Notes}

1. Many more examples can be cited. In Europe alone, see the European regional policy, the 'Region Urbaine' policies in France, the Ghent Canal Area, the Öresund Region in Denmark and Sweden, the Milanese Città di Città, and the Limmat valley in Switzerland.

2. A more complete exegesis can be found in Neuman (2000).

3. As of this writing, there are four designated macro-region strategies in the EU: Baltic Sea Region (2009), Danube River Region (2010), Adriatic and Ionian Sea Region (2014) and the Alpine Region (2015). http://ec.europa.eu/regional_policy/en/policy/cooperation/ macro-regional-strategies/.

\section{Acknowledgements}

We thank Alain Thierstein for his valuable comments on an earlier version of this paper.

\section{Disclosure statement}

No potential conflict of interest was reported by the authors.

\section{References}

Alaily-Mattar, N., Thierstein, A., \& Förster, A. (2014). Alternative futures: A methodology for integrated sustainability considerations, the case of Nuremberg West, Germany. Local Environment: The International Journal of Justice and Sustainability, 19(6), 677-701. doi:10.1080/13549839. 2013.841135

Alawadi, K., \& Benkraouda, O. (2017). What happened to Abu Dhabi's urbanism? The question of regional integration. Journal of Urban Design. doi:10.1080/13574809.2017.1361786

Albrechts, L. (1999). Planners as catalysts and initiators of change. The new structure plan for Flanders. European Planning Studies, 7(5), 587-603. doi:10.1080/09654319908720540

Albrechts, L., Balducci, A., \& Hillier, J. (2016). Situated practices of strategic planning: An international perspective. London: Routledge.

Alexander, C., Ishikawa, S., Silverstein, M., Jacobson, M., Fiksdahl-King, I., \& Angel, S. (1977). A pattern language: Towns, buildings, construction. New York, NY: Oxford University Press.

Balz, V., \& Zonneveld, W. (2015). Regional design in the context of fragmented territorial governance: South Wing studio. European Planning Studies, 23(5), 871-891. doi:10.1080/09654313.2014.889662

Bisker, J., Chester, A. \& Eisenberg, T. (Eds.) (2015). Rebuild by design. Retrieved from http://www. rebuildbydesign.org/data/files/499.pdf

Burger, J., O’Neill, K. M., Handel, S. N., Hensold, B., \& Ford, G. (2017). The shore is wider than the beach: Ecological planning solutions to sea level rise for the Jersey Shore, USA. Landscape and Urban Planning, 157, 512-522. doi:10.1016/j.landurbplan.2016.08.017

Center for Urban Policy Research. (1992). Impact assessment of the New Jersey Interim State Development and Redevelopment Plan. Trenton: NJ State Planning Commission.

Cotella, G., \& Janin Rivolin, U. (2011). Europeanization of spatial planning through discourse and practice in Italy. disP - The Planning Review, 47(186), 42-53. doi:10.1080/02513625.2011.10557143 
De Bruijn, J. A., \& Ten Heuvelhof, E. F. (1999). Scientific expertise in complex decision-making processes. Science and Public Policy, 26(3), 179-184. doi:10.3152/147154399781782428

De Jonge, J. (2009). Landscape architecture between politics and science: An integrative perspective on landscape planning and design in the network society. Wageningen: Blauwdruk/Techne Press.

De Roo, G., \& Porter, G. (2016). Fuzzy planning: The role of actors in a fuzzy governance environment (2nd edn). London: Routledge.

Dupuy, G. (1991). L'Urbanisme des réseaux: Théories et méthodes. Paris: Armand Colin.

Dühr, S. (2007). The visual language of planning: Exploring cartographic representations for spatial planning in Europe. London: Routledge.

Dühr, S., \& Zonneveld, W. (2012). Images of Europe, images for Europe. In W. Zonneveld, J. de Vries, \& L. Janssen-Jansen (Eds.), European territorial governance (pp. 281-308). Amsterdam: IOS Press.

European Commission. (2016). Report from the Commission to the European Parliament, the Council, the European Economic and Social Committee and the Committee of the Regions. Brussels: Author.

Faludi, A. (1996). Framing with images. Environment and Planning B: Planning and Design, 23(1), 93-108. doi:10.1068/b230093

Faludi, A. (2003a). Unfinished business: European spatial planning in the 2000s. Town Planning Review, 74(1), 121-140. doi:10.3828/tpr.74.1.7

Faludi, A. (2003b). The application of the European spatial development perspective. Town Planning Review, 74(1), 1-9. doi:10.3828/tpr.74.1.1

Faludi, A. (2013). Territorial cohesion, territorialism, territoriality, and soft planning: A critical review. Environment and Planning A, 45(6), 1302-1317. doi:10.1068/a45299

Faludi, A., \& Van der Valk, A. (1994). Rule and order: Dutch planning doctrine in the twentieth century. Dordrecht: Kluwer Academic.

Faludi, A. \& Waterhout, B (2002). The making of the European spatial development perspective. London: Routledge.

Fernández de los Ríos, Á. (1868). El futuro Madrid: Paseos mentales por la capital de España, tal cual es y tal cual debe dejarla transformada la revolución. Madrid: Biblioteca Universal Económica. [Republished 1989, with a forward by Antonio Bonet Correa].

Friedmann, J., \& Weaver, C. (1980). Territory and function: The evolution of regional planning. Berkeley: University of California Press.

Geddes, P. (1915). Cities in evolution. London: Williams and Norgate.

Geertz, C. (1983). Local knowledge: Further essays in interpretive anthropology. New York, NY: Basic Books.

Hajer, M. A. (2010). Authoritative governance: Policy making in the age of mediatization. Oxford: Oxford University Press.

Hajer, M., \& Versteeg, W. (2005). Performing governance through networks. European Political Science, 4(3), 340-347. doi:10.1057/palgrave.eps.2210034

Hegemann, W. \& Peets, E. (1922). The American Vitruvius: An architects' handbook of civic art. New York, NY: Architectural Book Publishing.

Howard, E. (1898). To-morrow: A peaceful path to real reform. London: Swan Sonnenschein.

Innes, J., Gruber, J., Neuman, M., \& Thompson, R. (1994). Coordinating growth and environmental management through consensus building. Report to the California Policy Seminar, Berkeley, California.

Kelbaugh, D. (1997). Common place: Toward neighborhood and regional design. Seattle: University of Washington Press.

Kozlowski, M. (2006). The emergence of urban design in regional and metropolitan planning: The Australian context. Australian Planner, 43(1), 36-41. doi:10.1080/07293682.2006.9982463

Lang, R., \& Knox, P. (2009). The new metropolis: Rethinking megalopolis. Regional Studies, 43(6), 789-802. doi:10.1080/00343400701654251

Lewis, P. (1996). Tomorrow by design: A regional design process for sustainability. New York, NY: Wiley.

Lynch, K. (1976). Managing the sense of a region. Cambridge: MIT Press. 
MacKaye, B. (1921). An Appalachian trail: A project in regional planning. Journal of the American Institute of Architects, 9, 325-330.

McHarg, I. (1969). Design with nature. New York, NY: Doubleday/Natural History Press.

Meyer, H., Bobbink, I., \& Nijhuis, S. (2010). Delta urbanism: The Netherlands. Chicago: American Planning Association.

Mumford, L. \& MacKaye, B. (1931, July). The townless highway. The Nation, p. 163.

National Infrastructure Commission. (2017a). The Cambridge to Oxford connection: Ideas competition. London: Author.

National Infrastructure Commission. (2017b). Partnering for prosperity: A new deal fort the Cambridge-Milton Keynes-Oxford Arc. London: Author.

Neuman, M. (1996). Images as institution builders: Metropolitan planning in Madrid. European Planning Studies, 4(3), 293-312. doi:10.1080/09654319608720347

Neuman, M. (2000). Regional design: Recovering a great landscape architecture and urban planning tradition. Landscape and Urban Planning, 47, 115-128. doi:10.1016/S0169-2046(99)00079-1

Neuman, M. (2005). The compact city fallacy. Journal of Planning Education and Research, 25(1), 11-26. doi:10.1177/0739456X04270466

Neuman, M. (2007). Multi-scalar large institutional networks in regional planning. Planning Theory and Practice, 8(3), 319-344. doi:10.1080/14649350701514645

Neuman, M. (2011). Centenary paper: Ildefons Cerdà and the future of spatial planning: The network urbanism of a city planning pioneer. Town Planning Review, 82(2), 117-144. doi:10. 3828/tpr.2011.10

Neuman, M. (2014). Rethinking borders. In W. Steele, T. Alizadeh, \& L. Eslami-Andargoli (Eds.), Planning across borders (pp. 15-30). London: Routledge.

Neuman, M. (2016). Teaching collaborative and interdisciplinary service-based urban design and planning studios. Journal of Urban Design, 21(5), 596-615. doi:10.1080/13574809.2015.1100962

Neuman, M., \& Hull, A. (2011). The futures of the city region. London: Routledge.

New Jersey Office of State Planning. (1990). The regional design system. Trenton: Author.

New Jersey State Planning Commission. (1992). Communities of place: The New Jersey State Development and Redevelopment Plan. Trenton: Author.

Olesen, K., \& Albrechts, L. (2017). Changing planning discourses and practice: The Flanders Structure Plan; Kristian Olesen in conversation with Louis Albrechts. AESOP Young Academics Booklet Series C: Exploring Place matters in Planning, Booklet 1.

Ovink, H. (2015). Reform by design. Journal of Extreme Events, 2(1), 7-14. doi:10.1142/ S2345737615020017

Regional Plan Association. (1929). Regional plan for New York and environs. New York, NY: Author.

Regional Plan Association. (2017). The fourth regional plan: Making the region work for all of us. New York, NY: Author.

Regional Planning Association of America. (1925, May). Survey Graphic 7, entire issue.

Ryser, J., \& Franchini, T. (2015). International manual of planning practice. The Hague: International Society of City and Regional Planners ISOCARP.

Salet, W., \& Faludi, A. (2000). Three approaches to strategic spatial planning. In W. Salet \& A. Faludi (Eds.), The revival of strategic spatial planning (pp. 267-280). Amsterdam: Royal Netherlands Academy of Arts and Sciences.

Salewski, C. (2012). Dutch new worlds: Scenarios in physical planning and design in the Netherlands, 1970-2000. Rotterdam: 010 Publishers.

Sijmons, D., Hugtenburg, J., Feddes, F., \& Van Hoorn, A. (2014). Landscape and energy: Designing transition. Rotterdam: nai010 publishers.

Spirn, A. W. (2000). Ian McHarg, landscape architecture, and environmentalism: Ideas and methods in context, in Michel Conan. Environmentalism in landscape architecture. Washington, DC: Dumbarton Oaks Research Library.

Stead, D. (2014). European integration and spatial rescaling in the Baltic region: Soft spaces, soft planning and soft security. European Planning Studies, 22(4), 680-693. doi:10.1080/09654313.2013.772731 
Throgmorton, J. A. (1996). Planning as persuasive storytelling: The rhetorical construction of Chicago's electric future. Chicago: University of Chicago Press.

Throgmorton, J. A. (2003). Planning as persuasive storytelling in a global-scale web of relationships. Planning Theory, 2(2), 125-151. doi:10.1177/14730952030022003

Van de Riet, O. A. W. T. (2003). Policy analysis in a multi-actor policy settings: Navigating between negotiated nonsense \& superfluous knowledge. Delft: Eburon.

Van den Broeck, J. (1997). The spatial development perspective for the Benelux. Built Environment, 23(1), 14-26.

White, J. T. (2015). Future directions in urban design as public policy: Reassessing best practice principles for design review and development management. Journal of Urban Design, 20(3), 325-348. doi:10.1080/13574809.2015.1031212

Yaro, R., \& Hiss, T. (1996). A region at risk. New York, NY: Regional Plan Association.

Zonneveld, W. (2005a). Expansive spatial planning: The new European transnational spatial visions. European Planning Studies, 13(1), 137-155. doi:10.1080/0965431042000312442

Zonneveld, W. (2005b). Multiple visioning: New ways of constructing transnational spatial visions. Environment and Planning C: Government and Policy, 23(1), 41-62. doi:10.1068/c37m 